\title{
PENGGUNAAN APLIKASI VIDEOMAKER FX DALAM PENGEMBANGAN MEDIA PEMBELAJARAN BAHASA INDONESIA
}

\author{
Reflection of Feminism in Aini Teacher Novel \\ by Andrea Hirata
}

Naurah Khairunnisa

UIN Syarif Hidayatullah Jakarta

naurakhairunnisa@gmail.com

\begin{abstract}
Abstrak
Perkembangan zaman yang sangat pesat pastinya berpengaruh terhadap teknologi informasi dan komunikasi, termasuk pada bidang Pendidikan. Salah satu dari produk teknologi informasi dan komunikasi yang sangat menarik untuk dimanfaatkan dalam pembelajaran adalah aplikasi VideoMaker FX ini. Dalam pemanfaatan media, diperlukan kreativitas dan juga pertimbangan instruksional yang matang dari pengajar. Kenyataannya banyak pengajar yang menggunakan media pembelajaran seadanya tanpa pertimbangan pembelajaran. Penelitian ini bertujuan untuk menghasilkan media pembelajaran Bahasa Indonesia menggunakan aplikasi VideoMaker FX di sekolah yang praktis, mudah dan efektif terhadap pembelajaran siswa. Metode penelitian yang digunakan adalah metode kualitatif deskripsi, dengan cara mendeskripsikan penggunaan aplikasi VideoMaker FX sebagai pengembangan media video pembelajaran.
\end{abstract}

Kata Kunci: VideoMaker FX; Media Pembelajaran; Teknologi Pembelajaran

\begin{abstract}
The very rapid development of the era certainly affects information and communication technology, including in the field of education. One of the information and communication technology products that is very interesting to use in learning is the VideoMaker FX application. In utilizing the media, creativity and careful instructional considerations from the teacher are needed. In fact, many teachers use improvised learning media without considering learning. This study aims to produce Indonesian language learning media using the VideoMaker FX application in schools that is practical, easy and effective for student learning. The research method used is descriptive qualitative method, by describing the use of the VideoMaker FX application as a learning video media development.
\end{abstract}

Keywords: VideoMaker FX; Learning Media; learning technologies

\section{PENDAHULUAN}

Perkembangan zaman yang sangat pesat juga berpengaruh kepada perkembangan ilmu pengetahuan dan ilmu teknologi yang membawa perubahan yang cukup signifikan dalam aspek kehidupan manusia, dengan majunya ilmu teknologi mempermudah manusia dalam mencari dan mendapatkan informasi. Salah satu bidang yang mendapatkan dampak cukup berarti dalam perkembangan ini adalah bidang pendidikan, dimana pada dasarnya pendidikan merupakan suatu proses komunikasi dan informasi antara guru kepada siswa yang berisi informasi-informasi pendidikan, yang memiliki unsur-unsur pendidikan sebagai informasi, media sebagai penyajian ide, gagasan dan materi pendidikan serta siswa itu sendiri. 
Pendidikan adalah salah satu komponen terpenting dalam pembangunan sumber daya manusia. Melalui Pendidikan yang berkualitas diharapkan sumber daya manusia akan menjadi lebih baik lagi. Perkembangan ilmu pengetahuan dan ilmu teknologi tersebut patutlah diberdayakan oleh guru untuk membantu mewujudkan keberhasilan kegiatan belajar dalam dunia pendidikan. Dalam dunia pendidikan guru sangat berperan aktif dalam peningkatan mutu, salah satunya adalah guru harus kreatif dan inovatif membuat media pembelajaran sendiri dengan memanfaatkan teknologi yang berkembang pesat saat ini. Kemajuan ilmu teknologi menuntut guru agar bisa memanfaatkan dan mampu menggunakan alat-alat teknologi yang telah tersedia. Melalui Pendidikan yang berkualitas diharapkan sumber daya manusia akan menjadi lebih baik lagi mengoptimalkan mutu Pendidikan saat ini, guru juga dituntut untuk dapat mengembangkan keterampilan membuat media pembelajaran yang akan digunakannya maka diperlukannya berbagai upaya dalam pengembangan media pembelajaran.

Pembelajaran adalah suatu kegiatan yang bertujuan. Tujuan ini harus searah dengan tujuan belajar siswa dan kurikulum. Tujuan belajar siswa ialah mencapai perkembangan optimal, yang meliputi aspek kognitif, afektif, dan psikomotorik. Dengan demikian tujuan pembelajaran adalah agar siswa emncapai perkembangan optimal dalam ketiga aspek tersebut. (Cecep: 20, 2).

Media pembelajaran merupakan penyalur atau pembawa pesan (guru) kepada penerima pesan (peserta didik) dalam proses pembelajaran, yang diharapkan dapat merangsang perhatian, motivasi, minat, dan perasaan peserta didik dalam kegiatan belajar sehingga, tujuan pembelajaran dapat tercapai. Peran media pembelajaran merupakan perantara atau alat untuk memudahkan proses belajar mengajar agar tercapai tujuan pengajaran yang efektif dan efesien. Media pembelajaran adalah alat atau metode dan teknik yang digunakan sebagai perantara komunikasi antara seorang guru dan siswa dalam rangka lebih mengefektifkan komunikasi dan interaksi antara guru dan siswa dalam peroses pembelajaran di sekolah, sangat bermanfaat untuk di masyarakatkan. Media pembelajaran didalamnya melibatkan siswa, baik dalam mental ataupun dalam bentuk aktifitas yang nyata sehingga fungsi pembelajaran dapat terlaksana. Materi pada media pembelajaran harus dirancang secara sistematis dan semenarik mungkin. Selain menyenangkan, media pembelajaran dapat meningkatkan keinginan dan minat belajar dalam memahami materi yang akan disampaikan oleh guru.

Salah satu yang mempengaruhi keberhasilan siswa dalam pembelajaran adalah kelengkapan saran atau media yang digunakan serta pemanfaatan media yang tepat sesuai kebutuhan, karena penggunaan media yang kurang tepat mengakibatkan pemncapaian hasil yang belajar yang kurang maksimal. Semakin bervariasi media yang digunakan maka pesan atau materi pembelajaran yang disampaikan akan semakin optimal diterima oleh peserta didik. Variasi dan keragaman modalitas belajar siswa bisa terakomodasi dari media yang variatif dalam pembelajaran. Penggunaan media yang bervariasi dan juga tepat diharapkan agar siswa lebih mudah memahami maksud dari materi yang diajarkan serta dapat menghilangkan rasa kejenuhan ataupun kebosanan dalam proses pembelajaran, selain itu juga dapat memudahkan guru untuk membagi ilmu pengetahuan kepada para siswa. 
Pada era globalisasi yang sudah sangat maju ilmu teknologinya yang juga berpengaruh kepada bidang Pendidikan. Perkembangan ilmu pengetahuan dan teknologi mendorong upaya pembaruan dalam pemanfaatan hasil-hasil teknologi dalam proses belajar. Pergeseran paradigma Pendidikan khususnya dalam pembelajaran dikelas sudah seharusnya mengikuti perkembangan teknologi. Adapuan teknoligi Pendidikan yang merupakan pengembangan, penerapan, dan penilaian system-sistem, tenik dan alat bantu untuk memperbaiki dan meningkatkan proses belajar manusia. Teknologi Pendidikan merupakan pemanfaatan dan pengetahuan spesifik dari perkakas dan keterampilan dalam Pendidikan. (Ahmad:20, 8)

Pentingnya guru dalam mengikuti perkembangan zaman ini, dengan mengikuti minat siswa. Dengan begitu murid akan semakin tertarik dan bersemangat dalam proses belajar. Juga dengan memanfaatkan teknologi yang ada akan memudahkan guru maupun murid dalam mempelajari materi pelajaran, dan pastinya murid akan lebih paham bila menggunakan fasilitas teknologi yang dimana pada zaman sekarang siswa hidup sudah bersanding dengan teknologi yang canggih, bahkan murid pada sekolah dasar saja sudah banyak yang mengerti menggunakan handphone.

Pemanfaatan teknologi dalam pengembangan media pembelajaran dengan memanfaatkan teknologi yang berkembang pesat saat ini salah satunya adalah memanfaatkan program yang ada di komputer atau laptop yaitu videomaker FX sebagai media pembelajaran. Dengan videomaker FX, seorang guru dapat membuat video pembelajaran yang interaktif, menarik, dan menyenangkan. Penggunaan media pembelajaran interaktif merupakan salah satu cara yang dapat digunakan guru untuk meningkatkan prestasi belajar peserta didik. Penggunaan media pembelajaran interaktif diharapkan membantu peserta didik dalam memahami dan menerima proses pembelajaran yang dilakukan guru. Media pembelajaran interaktif dapat mewakili apa yang belum bisa disampaikan guru dan proses pembelajaran akan lebih efektif dan efisien. Video pembelajaran bisa digunakan ulang oleh siswa di rumah dengan menggunakan computer atau handphone dan tentunya media ini lebih menyenangkankan untuk digunakan sebagai sarana belajar daripada menggunakan buku ajar biasa.

VideoMaker FX merupakan aplikasi editing video yang dibuat oleh Peter Roszak. Aplikasi ini membantu dalam pembuatan video dengan cepat, mudah dan tidak memakan waktu lama. VideoMaker FX dapat digunakan untuk membuat video ulasan produk atau promosi, presentasi dan juga bahan ajar. VideoMaker FX cocok digunakan oleh pengguna yang memang benar-benar belum memahami tentang editing video. Aplikasi ini dapat menjadi referensi guru untuk membantu dalam pembuatan media video pembelajaran yang menarik, dan juga menyenangkan serta interaktif. Video pembelajaran yang dihasilkan dapat dimanfaatkan untuk pembelajaran interaktif di kelas, baik oleh siswa maupun guru untuk presentasi online maupun offline. Pemanfaatan aplikasi VideoMaker FX sebagai media pembelajaran dapat digunakan setiap saat, dengan syarat adanya computer atau laptop yang sudah terinstall aplikasi ini.

Penggunaan VideoMaker FX dalam pembuatan video pembelajaran dapat diterapkan dalam pembelajaran bahasa Indonesia. Pelajaran bahasa Indonesia pada umumnya tidak dianggap oleh siswa sebagai pelajaran yang sukar, sehingga menurut siswa pelajaran bahasa 
Indonesia cukup membosankan. Para siswa tidak pernah mengategorikannya sebagai mata pelajaran yang sukar seperti halnya Pelajaran Matematika, Fisika, Bahasa Inggris, dan lainlain. Tetapi pada kenyataannya nilai hasil belajar siswa pada mata pelajaran bahasa Indonesia tidak lebih baik dari mata pelajaran yang dianggap sukar bagi siswa. Permasalahan ini muncul bukan hanya karena kemampuan dan motivasi belajar siswa yang kurang, tetapi juga faktor lingkungan belajar yang kurang mendukung. Dalam hal ini kreativitas guru bahasa Indonesia dalam mengelola pembelajaran mempunyai pengaruh yang sangat besar dalam meningkatkan hasil belajar siswa.

Media pembelajaran berbasis video juga memiliki fungsi-fungsinya, seperti yang dipaparkan oleh Levie dan Lentz bahwa media pembelajaran memiliki empat fungsi, khususnya media visual. Pertama, fungsi atensi. fungsi atensi media visual merupakan inti, yaitu menarik dan mengarhkan perhatian siswa untuk berkonsentrasi terhadap isi pelajaran yang berkaitan dengan makna visual yang ditampilkan atau menyertai teks materi pelajaran. Kedua, fungsi afektif. Media visual dapat dari tingkat kenyamanan siswa ketika belajar (atau membaca) teks yang bergambar. Ketiga, fungsi kognitif. Terlihat dari temuan-temuan penelitian yang mengungkapkan bahwa gambar visual mempermudah pencapaian tujuan untuk memahami dan mengingat informasi yang ada dalam gambar. Keempat, fungsi kompensatoris. Terlihat dari hasil penelitian bahwa media visual yang memberikan konteks untuk memahami teks membantu siswa yang lemah dalam membaca untuk mengorganisasikan informasi dalam teks dan mengingatnya kembali. (Rudy, 2017:12-13)

Beberapa penelitian juga sudah membahas perihal pemanfaatan video pembelajaran sebagai media pembelajaran, baik pada pelajaran bahasa Indonesia maupun pelajaran lainnya. Namun, bila pada penelitian tersebut membahas tentang pemanfaatan video pembelajaran maka penelitian ini akan membahas media yang digunakan dalam pembuatan video pembelajaran. Pada penelitian-penelitian lainnya juga sudah ada yang membahas penggunaan aplikasi ataupun aplikasi dalam pembuatan video pembelajaran seperti videomaker, youtube dan lainnya, maka pada penelitian ini membahas aplikasi VideoMaker FX dalam membuat video pembelajaran. Penelitian ini juga bertujuan untuk mengedukasi dan memberikan referensi kepada guru ataupun murid atau lainnya yang membutuhkan media pada pembuatan video pembelajaran. Maka, penelitian ini akan memberikan referensi media untuk membuat video pembelajaran, yaitu aplikasi VideoMaker FX.

\section{METODE}

Penelitian ini menggunakan metode penelitian deskriptif kualitatif. Penelitian deskriptif yaitu mengumpulkan data berdasarkan faktor- faktor yang menjadi pendukung terhadap objek penelitian, kemudian menganalisa faktor-faktor tersebut untuk dicari peranannya (Arikunto, 2010:151). Penelitian kualitatif merupakan penelitian yang berhubungan dengan ide, persepsi, pendapat, kepercayaan orang yang akan diteliti dan kesemuanya tidak dapat di ukur dengan angka. Penelitian kualitatif tidak menggunakan statistik, tetapi melalui pengumpulan data, analisis, kemudian di interpretasikan. Metode deskriptif dipilih karena penelitian yang dilakukan adalah berkaitan dengan peristiwaperistiwa yang sedang berlangsung dan berkenaan dengan kondisi masa sekarang. 


\section{HASIL DAN PEMBAHASAN}

Penggunaan aplikasi ini bisa diakses atau digunakan oleh siapa saja. Aplikasi ini merupakan aplikasi edit video yang sangat mudah, dan tidak terlalu membingungkan untuk pemula yang ingin mencoba membuat video animasi. Selain itu, VideoMaker FX tidak hanya berguna untuk pembuatan video pembelajaran saja, aplikasi ini bisa digunakan juga untuk membuat video ulasan produk atau promosi, presentasi, bisnis dan lainnya. Aplikasi ini juga memiliki beberapa keunggulan, seperti memilik puluhan tamplate yang sudah siap dipakai, jadi kita hanya memilih dan memakai tamplate yang sudah disediakan. Juga pada hasil video yang kita buat tidak memiliki watermark sehingga membuat video kita terlihat lebih professional dan lebih mudah tanpa harus membayar mahal untuk akun premium agar hasil video tidak terdapat watermark.

Tetapi, pada VideoMaker FX juga terdapat kekurangan karena aplikasi ini terbilang sangat mudah digunakan dan juga tidak rumit sehingga fitur yang disediakan juga tidak begitu banyak dan rumit seperti aplikasi edit video yang lainnya. Contohnya pada aplikasi ini kita hanya bisa memasukkan lagu atau music pada video, tetapi untuk audio yang berisikan penjelasan materi sebenarnya bisa saja namun sayangnya kita tidak bisa mengatur durasi audio penjelasan materi tersebut mau sampai mana atau sampai menit berapa audio tersebut di dalam video. Lalu dengan banyaknya tamplate bisa memudahkan dan juga menyulitkan dalam pembuatan video, karena dengan banyaknya pilihan terkadang akan membuat proses pemilihan tamplate menjadi lama karena mencari tamplate yang sesuai. Juga dengan tamplate yang telah disediakan terkadang ada yang kurang pas menurut kita tamplatenya dan ingin kita rubah tetapi tidak bisa.

Pada proses pembuatan video pembelajaran menggunakan aplikasi VideoMaker FX ini hal pertama yang harus dilakukan adalah dengan mengunduh aplikasi tersebut di google, atau boleh meminta file kepada kenalan yang sudah memiliki aplikasi ini. Setelah terpasang pada computer atau laptop maka lankah selanjutnya adalah dengan membuat akun. Namun, dalam pembuatan akun memang agak rumit, oleh karena itu ada pelatihan kelas VideoMaker FX ini. Lalu setelahnya kita akan melanjutkan tutorial dalam proses pembuatan video pembelajaran menggunakan aplikasi VideoMaker FX.

\section{Cara Pembuatan Video Pembelajaran Menggunakan VideoMaker FX}

Gambar 1. Tampilan untuk login ke dalam aplikasi

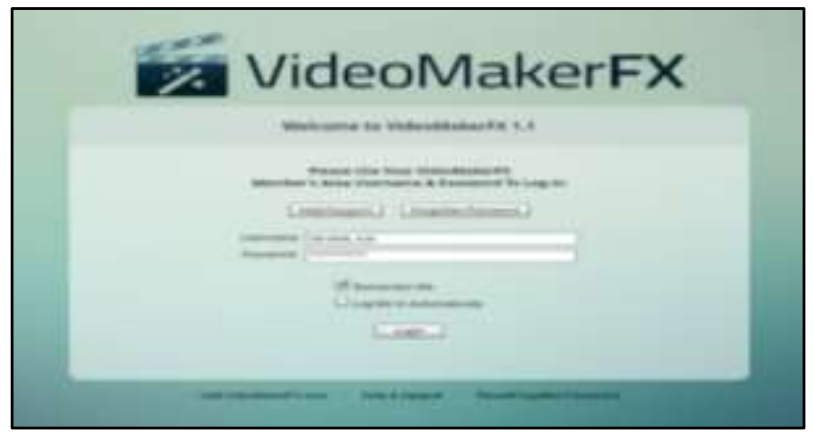


Langkah pertama setelah kita sudah selesai menginstall aplikasi adalah dengan melogin akun. Dapat dilihat pada gambar meruapakan tampilan yang pertama kali akan kita lihat bila membuka aplikasi VideoMaker FX. Lalu setelah memasukkan username dan password maka kita klik login untuk masuk.

Gambar 2. Tampilan layer setelah kita masuk ke dalam aplikasi

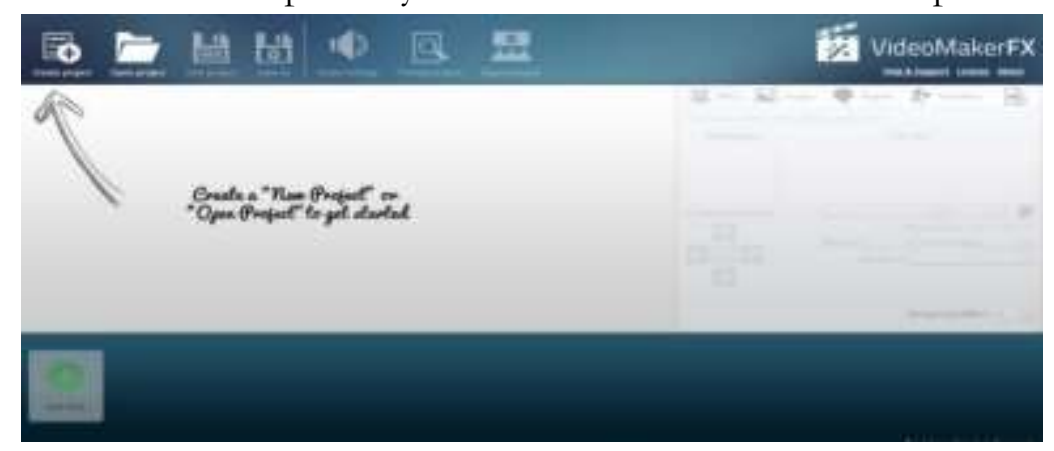

Pada gambar merupakan tampilan yang akan kita lihat setelah kita melogin akun, setelah login kita akan diarahkan untuk mengikuti instruksi tanda panah, yaitu mengklik create project. Create project merupakan pilihan untuk membuat proyek video yang nantinya akan kita buat.

Gambar 3. Tampilan untuk membuat dan memberi nama proyek video

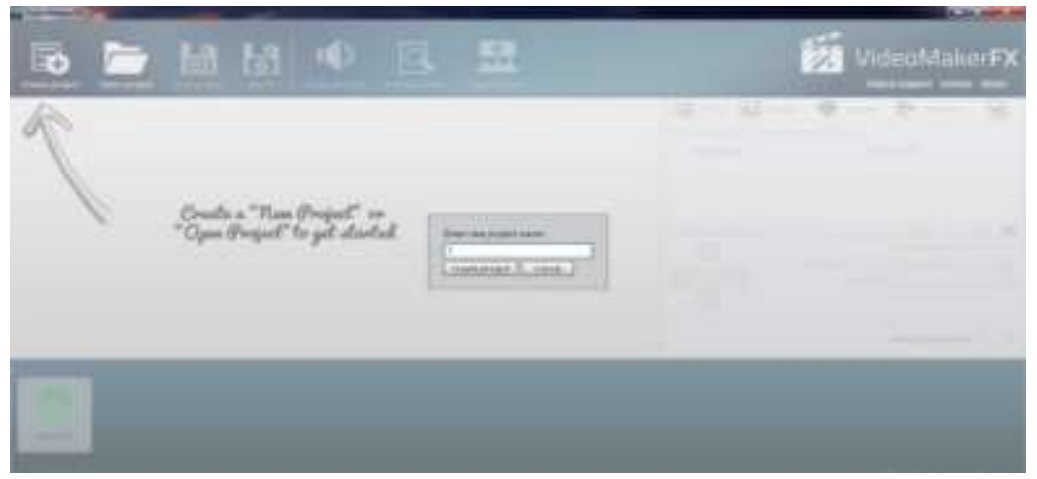

Pada gambar 3 merupakan tampilan setelah kita mengklik create project, setelahnya kita bisa mengatur nama untuk proyek video yang akan dibuat. Semisal nama proyeknya adalah "video pembelajaran bahasa Indonesia", setelah kita mengetik nama proyek maka klik Tulisa create project untuk menyimpan nama proyek video yang telah dibuat. 
Gambar 4. Tampilan untuk menambah slide atau tamplate

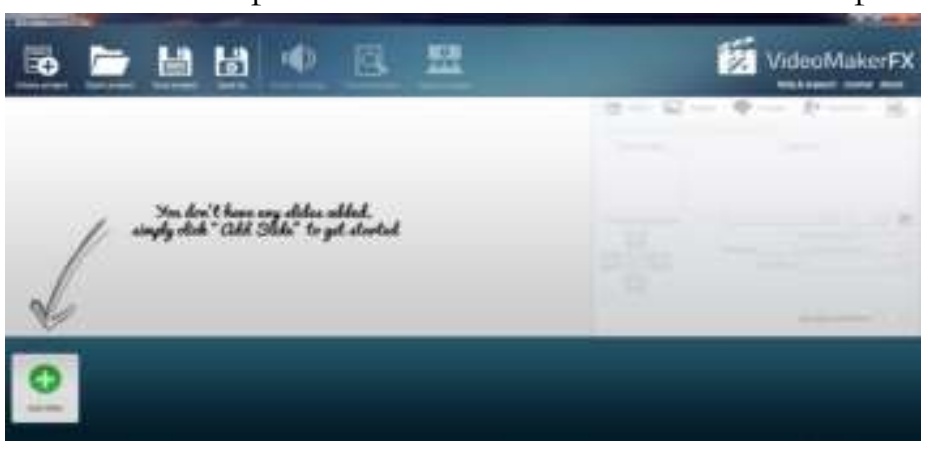

Setelah membuat nama proyek video yang akan dibuat, maka selanjutnya akan kembali diarahkan untuk mengikuti petunjuk tanda panah untuk memilih add slide. Pada fitur ini kita akan menambah slide yang kemudian diarahkan untuk memilih tamplate yang telah disediakan.

Gambar 5. Tampilan untuk memilih tamplate

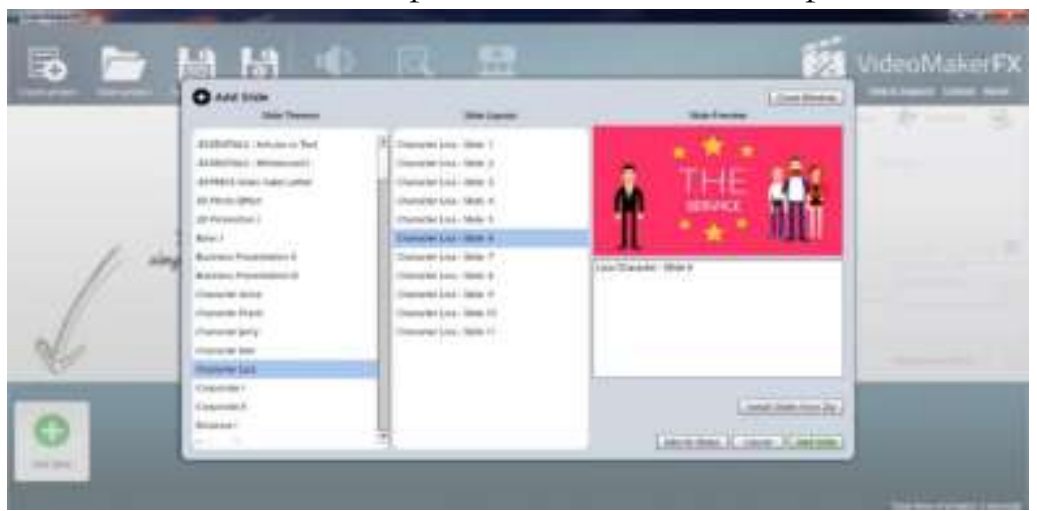

Pada gambar 5 merupakan tampilan setelah kita memilih add slide, setelahnya kita akan memilih tamplate yang kita butuhkan, ada banyak tamplate yang tersedia salah satunya adalah yang ditampilkan pada gambar. Kita bisa memilih banyak slide, bila sudah selesai dengan satu slide maka bisa memilih kembali add slide pada layar utama untuk menambah slide atau tamplate yang akan digunakan.

Gambar 6. Tampilan setelah tamplate sudah terpilih dan mengedit tulisan pada tamplate

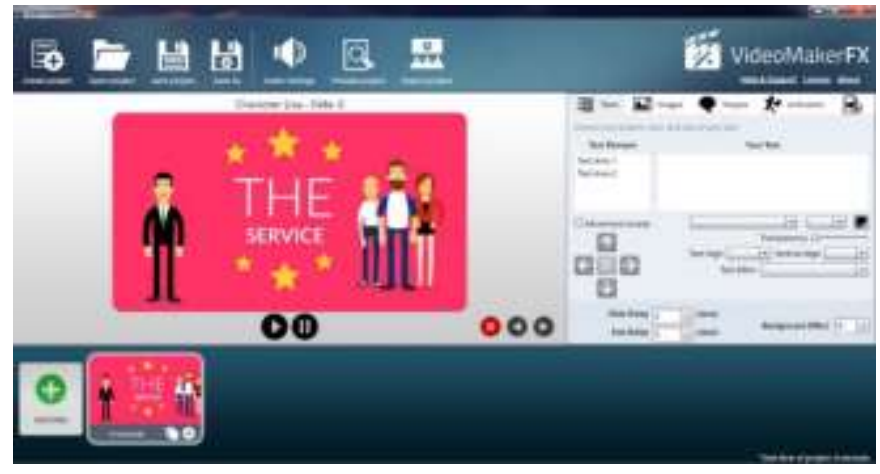


Pada gambar 6 merupakan tampilan tamplate yang telah kita pilih. Lalu kita bisa mengatur atau mengubah tulisan yang ada pada tamplate sesuai dengan yang kita inginkan. Untuk mengatur tulisan yang ingin kita ketik pilih pada fitur text, pillih text area 1 atau tex area 2. Setelahnya kita juga bisa mengatur font ataupun ukuran tulisan pada tamplate, juga bisa mengatur warna tulisan yang diinginkan.

Gambar 7. Tampilan untuk mengedit gambar pada tamplate

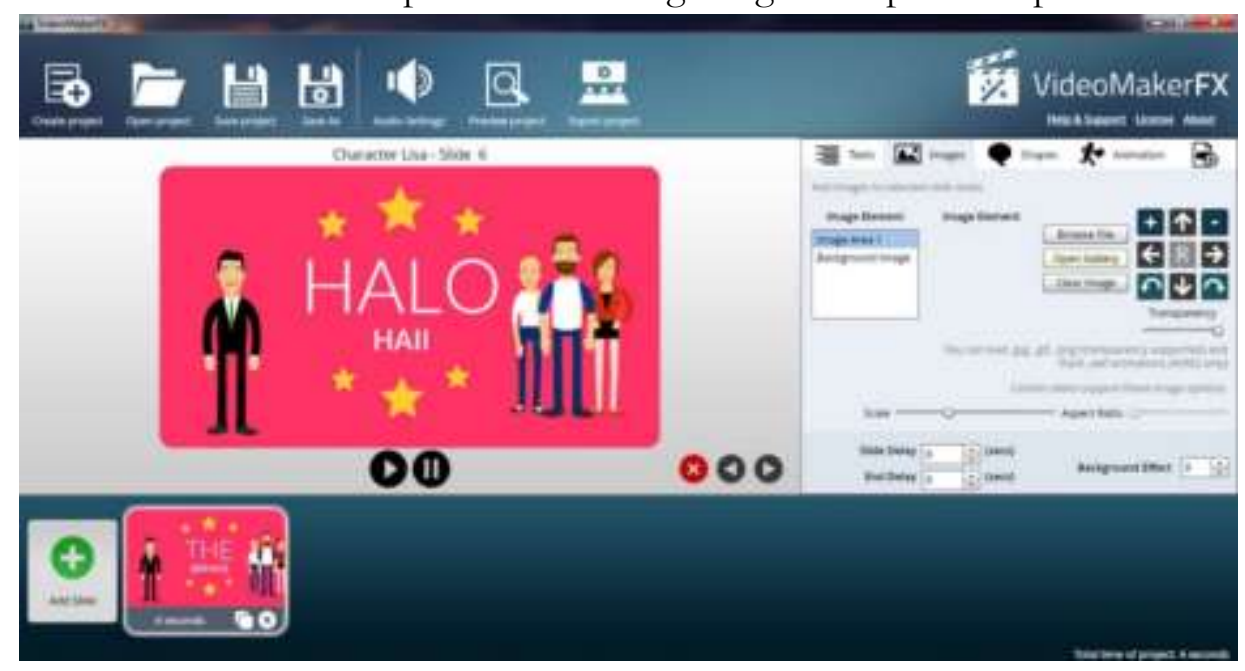

Pada gambar 7 menampilkan pilihan fitur image yaitu untuk menambahkan gambar pada tamplate, dengan cara memilih tulisan image area 1 atau background image untuk latar belakang gambar, lalu pilih open gallery untuk memilih gambar yang ada di galeri laptop atau computer kita. Selain itu kita juga bisa mengatur waktu atau durasi ayng diinginkan untuk satu slide atau tamplate pada bagian slide delay, kita bisa atur dari satu detik hingga seterusnya sesuai dengan yang kita inginkan.

Gambar 8. Tampilan untuk menambahkan audio

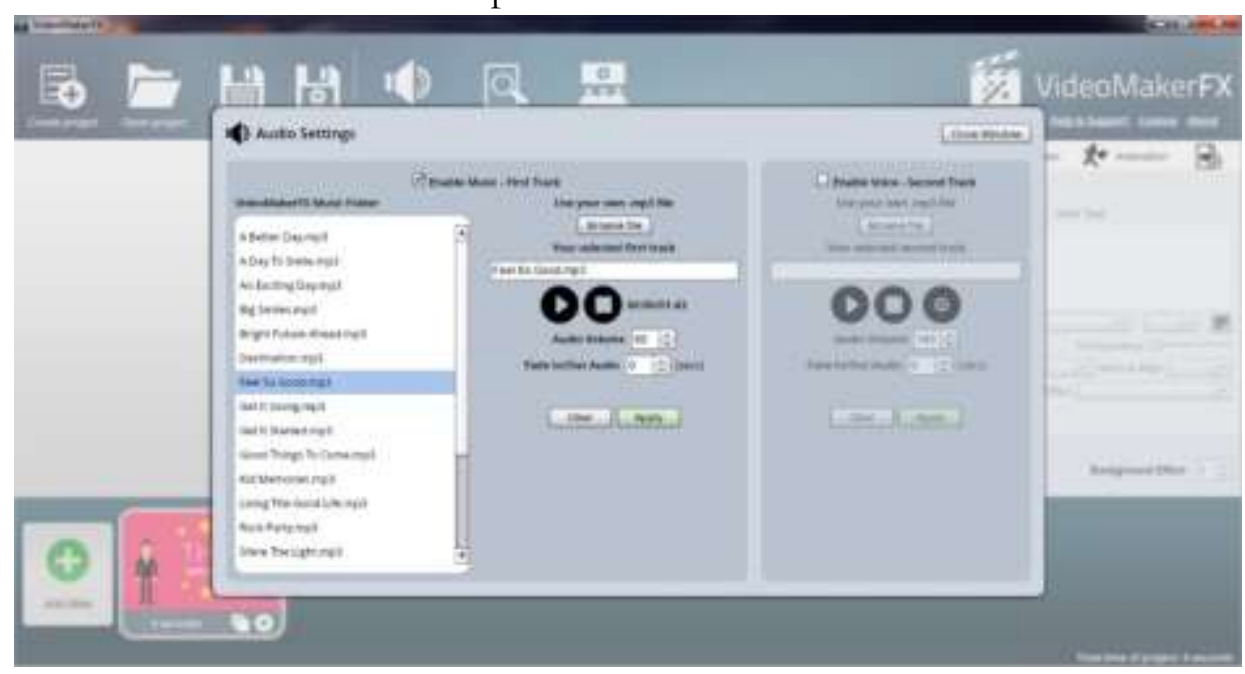


Pada gambar 8 merupakan tampilan apabila kita memilih audio setting, yaitu untuk mengatur suara atau music yang ingin kita tambahkan. Pada fitur ini juga sudah tersedia pilihan music, namun bila ingin menambahkan music dengan music milik sendiri maka pilih browse file untuk memilih music atau suara yang diinginkan, kita juga bisa mengatur volume pada music yang telah dipilih. Lalu setelah memilih klik apply untuk memasang music pada video.

Gambar 9. Tampilan untuk mengeksport video kita ke folder

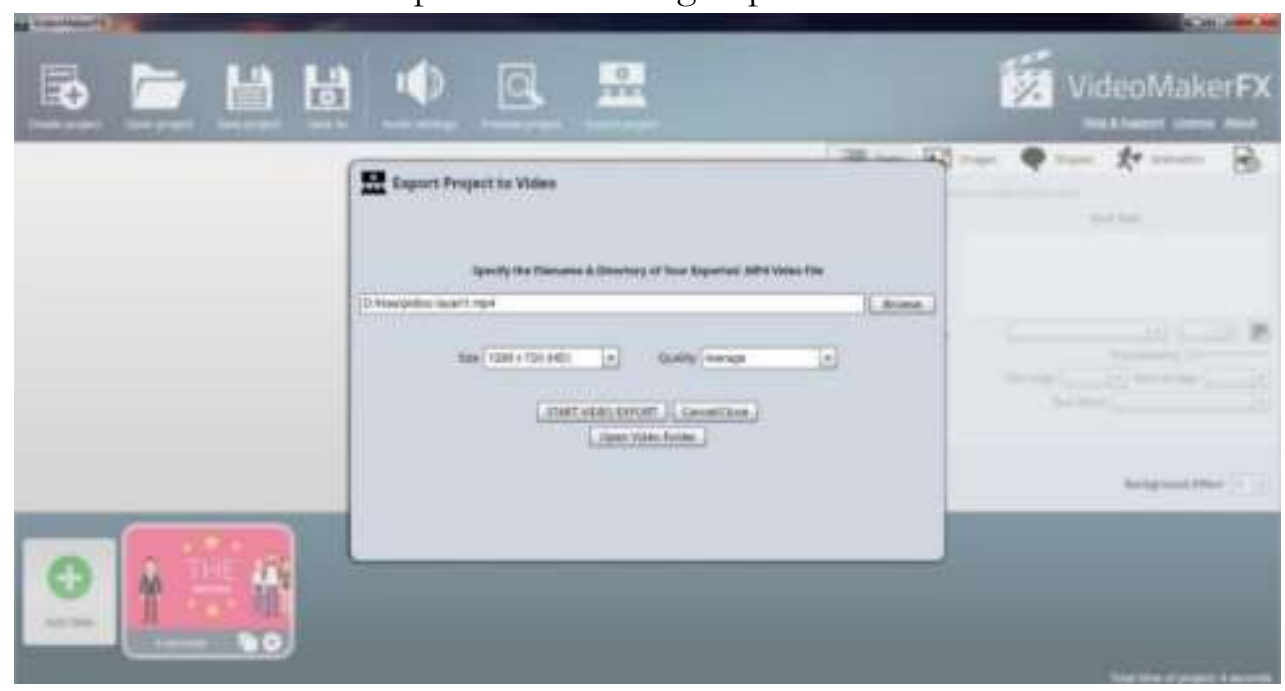

Pada gambar 9 merupakan tampilan apabila kita ingin menyimpan video yang telah kita buat ke folder. Maka klik export project, setelahnya klik browse untuk memilih folder yang akan kita simpan videonya. Kita juga bisa memilih ukuran atau resolusi dan kualitas video yang akan kita simpan. Setelahnya klik start video export untuk memulai menyimpan video ke perangkat atau folder yang sudah kita pillih. Lalu setelah selesai menyimpan buka folder tempat menyimpan video dan selesai video telah tersimpan.

\section{SIMPULAN}

Dari hasil dan pembahasan terkait materi tentang penggunaan aplikasi VideoMaker FX sebagai media pembelajaran maka dapat disimpulkan bahwa penggunaan aplikasi ini sangat membantu guru dalam membuat video pembelajaran, terlebih dalam masa pandemic seperti ini yang mengharuskan belajar secara online atau pembelajaran jarak jauh (PJJ). Dengan aplikasi ini juga memudahkan guru untuk mengdit atau membuat video pembelajaran dikarenakan aplikasi ini sangat mudah dan sudah tersedia banyak tamplate yang dapat digunakan dalam pembuatan video, sehingga guru hanya memilih dan menggunakan tamplate tersebut, aplikasi ini juga mirip seperti power point yang sudah tersedia tamplate dan tinggal memilih dan menggunakannya. Juga dengan pembuatan video pembelajaran dapat menambah metode pembelajaran dan semakin menarik sehingga siswa zaman sekarang akan lebih mudah memahami materi dalam bentuk video visual. 


\section{DAFTAR PUSTAKA}

Kustandi, Cecep dan Daddy Darmawan. 2020. Pengembangan Media Pembelajaran. Jakarta: Kencana.

Suryadi, Ahmad. 2020. Teknologi dan Media Pembelajaran Jilid I. Sukabumi: CV Jejak.

Sumiharsono, Rudy dan Hisbiyatus Hasanah. 2017. Media Pembelajaran: Buku Bacaan Wajib Dosen, Guru dan Calon Pendidik. Jember: Pustaka Abadi. 